\title{
A Discussion of Autonomy in the Relationship Between the Law Society of Upper Canada and the University-Based Law Schools
}

\section{THERESA SHANAHAN*}

Ontario Institute for the Studies in Education / University of Toronto

\begin{abstract}
This paper explores the relationship between the university-based common law schools and the Law Society of Upper Canada in legal education in Ontario today. A central objective of this paper is to distinguish between institutional autonomy and professional autonomy and to identify the competing interests and obligations of these two organizations involved in educating lawyers. In attempting to understand the differences between the autonomous bodies that govern legal education, a cross-disciplinary approach is taken to these issues combining a sociological framework on the professions with a legal perspective. The nature of professional identity and socialization, and the premise upon which professional responsibility and expertise are based is considered within the evolution of legal education in Ontario. This paper argues that the changes in organizational autonomy within the Law Society of Upper Canada and the law schools have shaped the relationship between

* Theresa Shanahan is a lawyer who has practised law in Toronto and served as a consultant to the Law Society of Upper Canada. She is presently a Ph.D. candidate in the Higher Education Group, Department of Theory and Policy Studies, OISE/UT. An earlier version of this paper was presented at the Annual Meeting of the American Educational Research Association, April 1999, Montreal, Canada. The author would like to thank Dr. Glen Jones, Dr. Jamie-Lynn Magnusson and Dr. Linda Muzzin for their comments on earlier drafts of this paper.
\end{abstract}


these two bodies and increased the law school's control over legal education. In so doing this shift has powerfully influenced the future of legal education in Ontario.

\section{RÉSUMÉ}

Ce document étudie le rapport actuel entre les facultés de droit des universités et le Barreau du Haut-Canada à l'égard de l'enseignement du droit en Ontario. Il vise essentiellement à faire la distinction entre l'autonomie des établissements d'enseignement et l'autonomie professionnelle et à cerner les intérêts et les obligations opposés de ces deux organismes qui offrent une formation aux avocats. Pour essayer de comprendre les différences entre les organismes autonomes qui régissent l'enseignement du droit, nous avons adopté une approche interdisciplinaire qui allie un cadre sociologique des professions et une perspective juridique. Nous étudions la nature de l'identité et de la socialisation professionnelles ainsi que le principe sur lequel sont basées la responsabilité et l'expertise professionnelles dans le cadre de l'évolution de l'enseignement du droit en Ontario. Ce texte soutient que les changements qu'a subis l'autonomie organisationnelle au sein du Barreau du Haut-Canada et des facultés de droit ont façonné le rapport qui existe entre ces deux organismes et fait augmenter le contrôle exercé par les facultés de droit sur l'enseignement du droit. Ce déplacement a donc eu une forte influence sur l'avenir de l'enseignement du droit en Ontario.

\section{INTRODUCTION}

The purpose of this paper is to describe the nature of institutional autonomy in the university-based law school and the professional autonomy of the Law Society of Upper Canada in order to better understand their roles and relationship within the context of legal education in Ontario. In attempting to understand the differences between the autonomous bodies that govern legal education, a sociological framework is employed to consider the nature of professionalism within these two organizations. The central objective of this paper is to distinguish 
between institutional autonomy and professional autonomy and to identify the competing interests and obligations of these two organizations involved in educating lawyers. This paper will explore the ground where the cultures of professional practice and the university meet in legal education.

It is my intention to take a cross-disciplinary approach to these issues using a sociological perspective on the professions and to combine it with my legal training and experience within the legal profession. This paper will review and integrate literature across disciplines using a Canadian case study of legal education in Ontario to explicate the theoretical analysis. Until recently, lawyers have escaped the rigorous attention of social science research. Twenty years ago Podmore (1977) observed that much of the writing on the legal profession had been "by lawyers, about lawyers, for lawyers" explaining that the legal profession has tended to be suspicious of research about itself because of its inherent conservatism, the confidential nature of the lawyer's role and because some lawyers considered it illegitimate to apply a scientific perspective to the study of law (cited in Stager \& Arthurs, 1990, pp. 8-9). More recently, Maru (1986), in an extensive review of research on the legal profession, commented that although research done on the legal profession had substantially increased "these studies have contributed less to one's understanding of the profession than their number might suggest, and we still do not have a clear outline of the nature and functioning of the profession" (Maru, 1986, p. 79). Reviews of the law profession and legal education in Canada identify a need for research into "changes in the degree of organizational autonomy and the means by which it is protected and exercised " (Stager \& Arthurs, 1990, pp. 7-8). This paper will explore the exercise of organizational autonomy in the university and the Law Society within Ontario. It seeks to understand the challenges autonomy presents to the relationship between the two bodies in an increasingly diverse profession and in light of the different perspectives on legal education between practitioners and academics.

For the purpose of this paper the consideration of autonomy will be confined to institutional autonomy of the university within which the law school operates and to professional autonomy of the Law Society 
within the context of self governance. While some structural and governance issues will be described to explain the nature of autonomy, this paper will not explore in depth the political aspects of the decisionmaking process within the two bodies. An important limitation of this article is that it focuses only on issues related to autonomy within the relationship between the Law Society of Upper Canada and the law schools within Ontario. It is not intended to be an exhaustive study of university or professional autonomy. Rather, this article focuses on the university-based portion of professional legal training which brings together the Law Society and the law schools. Furthermore, the analysis is developed within the context of Ontario and does not consider similar relationships between legal governing bodies and law schools in other jurisdictions. Although the analysis in this paper may suggest patterns that could apply across Canada, any general statements with respect to the legal profession and legal education must be qualified with reference to province given the autonomous nature of each governing body and the particular management of legal education within specific jurisdictions. The objective of this paper is to consider the autonomous nature of the bodies that are responsible for the education of lawyers in Ontario in order to better understand the factors that influence their relationship and, in turn, legal education.

The essay is organized into sections beginning with a brief review of sociological literature on the professions to ground the analysis in a theoretical framework. This is followed by an examination of role of professional autonomy within the governance of the Law Society of Upper Canada as it relates to the obligations of a self-governing profession. The changing role of the professional association and the law school in legal education is outlined as legal education moved from apprenticeship training to formal academic study. Institutional autonomy of the university and its impact on the administration of legal education within the law faculty are discussed. Finally, the present relationship between the two bodies is analysed in terms of their autonomous professional and institutional natures, and in terms of the implications for legal education. 


\section{THEORETICAL FRAMEWORK}

This paper adopts and extends a theoretical framework provided by sociologists investigating the professions. The professions, as a privileged group in society, have a major place in the theories of social organization. The sociology literature on the professions is enormous and wide ranging. It includes research on professional recruitment, the socialization process of professional education, professional prestige and power, and the relationship between the professional and their patients, clients and students. Attention to organizational structure and political governance are not generally considered from this perspective except as they relate to organizational behavior (Abbott, 1988; Carr-Saunders \& Wilson, 1933; Dingwall \& Lewis, 1983; Elliot , 1972; Freidson, 1983, 1986; Johnson, 1972; Krause, 1972; Larson, 1977; Moore, 1970; Pavalko, 1971). This analysis seeks to expand the consideration of professionalism and autonomy by including a discussion of governance.

Two approaches emerge from sociological literature in discussion of professions: the trait theories of professionalism and the power approach to professionalism. The earlier trait approach sought to distinguish the professions from other occupations by establishing essential features of a profession (Millerson, 1964). While this approach has defined the most salient features of the most powerful professions it can not definitively categorize all the professions across cultures and continents. Moreover, a consensus of attributes is not arrived at in the literature, but there are some common traits considered to comprise the general dimensions of the model profession (Johnson, 1972). These include: a body of specialized knowledge and techniques needed for professional work and specific education to master such knowledge and skills; a code of ethics which justifies self-regulation and underpins society's grant of autonomy; standards of competence enforced by the profession; strict controls over entry to the profession; legislative authority for self-regulation; and a service orientation in the direct and private relationship with the person being served (e.g., Eraut, 1994; Johnson, 1972; Larson, 1977; Millerson, 1964; Stager \& Arthurs, 1990). 
The trait models have proven inadequate in capturing the dynamics of the professional organization's activities. Consequently scholars shifted their attention from definitions of professions and began to examine the process of professionalization to understand how the professions gained their power and position in society over those they were intended to serve. The power approach examines professionalism as an instrument for social control (Freidson, 1970; Johnson, 1972; Larson, 1977). This alternate approach focuses on professionalism as an ideology which allows for an examination of the power dimension captured in the relationship between professional knowledge and societal control (e.g., Bella, 1996; Johnson, 1972; Larson, 1977). Bella (1996) has described the components of professions as ideology relying on Edward Shils' (1968) definition of ideology as a comprehensive pattern of beliefs that is explicit, systematized, integrated around specific values, demanding consensus, discouraging independent thought and action, and significantly, crafted to serve power over truth. Bella breaks down professional ideology into moral and pragmatic components, identifying the moral components of professionalism as: a work ethic based on the notion of a vocation; an ideal of service; and a version of noblesse oblige where rank imposes duty. The pragmatic components include: a monopoly of competence in a field, a restrictive access to the occupation; and the right to govern and discipline members. Relying on the work of Witz (1992) and Abbott and Wallace (1990), Bella (1996) argues that in pursuing their objectives, professions will demand adherence to the shared values of the occupation claiming they serve the interests of both the client and the broader public.

In both approaches the power of the professional lies in the social control of expertise which historically led to autonomy. It is justified on the basis of the public's need for experts to provide certain services based on knowledge that the public does not possess. To protect the public against incompetence and exploitation in the performance of these services by professionals, control is placed in the hands of the experts themselves because, it is argued, the state and the public are unable to adequately evaluate standards of professional competency. 
Eraut (1994), quoting Rueschemeyer (1983), describes the exchange from a functionalist perspective:

Individually and, in association, collectively, the professions 'strike a bargain with society' in which they exchange competence and integrity against the trust of client and community, relative freedom from lay supervision and interference, protection against unqualified competition as well as substantial remuneration and higher social status. (Rueschmeyer, 1983, p. 41)

Eraut (1994) argues that the freedom from state interference and external regulation given to the professions is based on their expertise, moral integrity, confidentiality and the premise of protection from political abuse. Moreover, protection against unqualified competition is necessary in circumstances where the public does not have the knowledge to discriminate and recognize when they are being deceived. In return the professions "guarantee the efficacy of their self-regulation by undertaking careful recruitment and training, promulgating codes of ethics and setting up committees to deal with any breaches of these codes" (Eraut, 1994, p. 2).

Diagram 1 illustrates the dynamic relationship between professions and the public as presented in sociological literature. Based on the specialized professional knowledge that professions offers the public through services rendered, the public, in confidence and trust grants professions autonomy in the form of self-governance. Attendant with these powers of self governance come professional responsibility and accountability to the public as demonstrated by the protection of the public interest, ensuring standards of competence and ethics. If a profession's knowledge base is compromised, or if a profession is unwillingly or unable to protect the public, a crisis of accountability occurs reversing the dynamic. In this situation the public's trust and confidence is undermined and public calls for increased government or external regulation of the profession arise representing a direct challenge on professional autonomy. Professional responsibility, then, secures society's grant of autonomy as represented in self-regulation. Professional education is critical to this relationship, and ultimately to professional autonomous power, because professional knowledge underpins the claims of autonomy and because it is a mechanism to demonstrate and ensure accountability. 
Diagram $1^{*}$

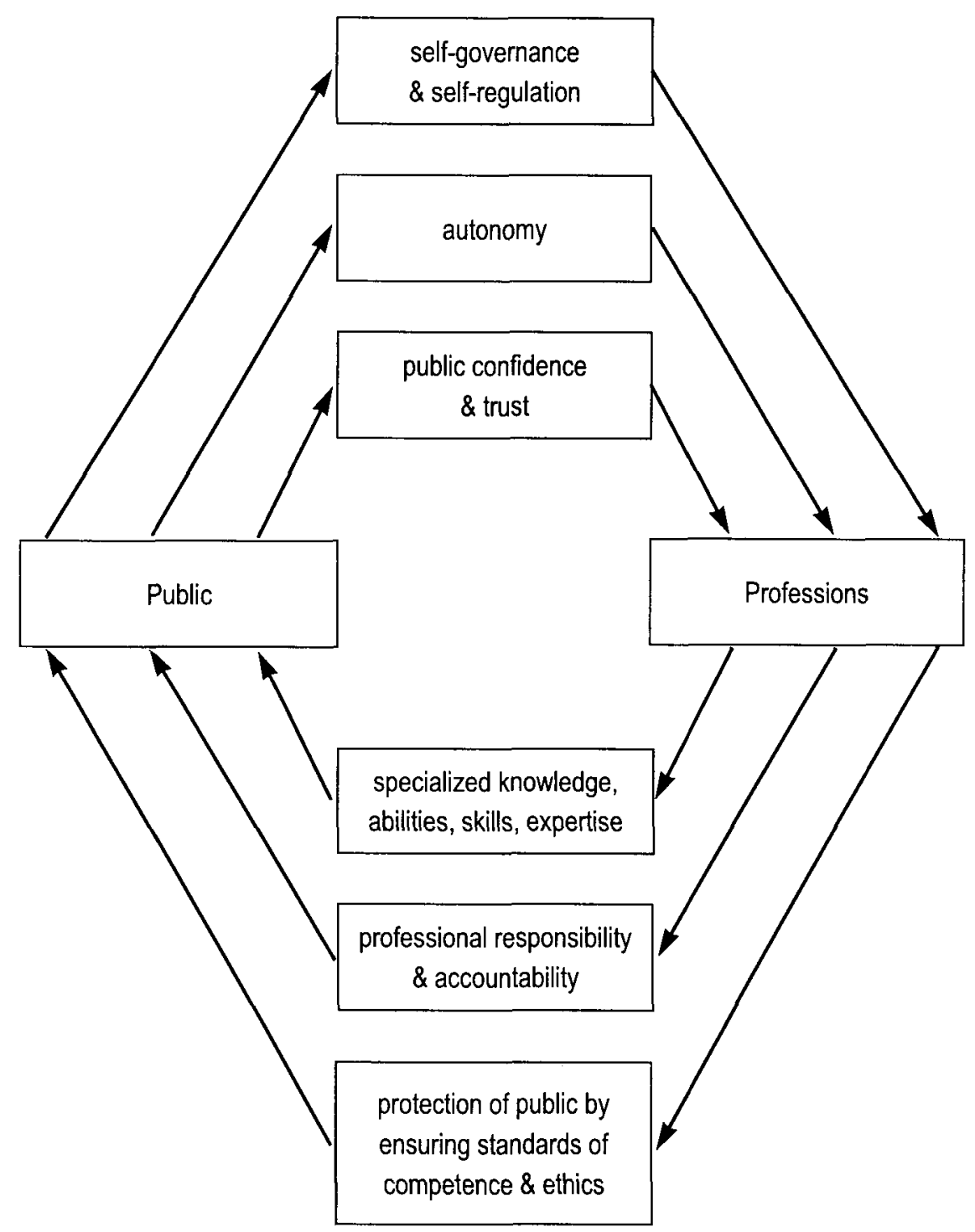

* This diagram represents my interpretation of sociological literature in this area. 


\section{PROFESSIONAL AUTONOMY}

Professional autonomy, identified as control over the profession and professional work and a monopoly over the provision of services, has been described as the core of professional power (Coburn, 1992). Professions offer special competence and mastery of bodies of knowledge valued by the society and in return they receive the right to control their own work (Friedson, 1986, Larson, 1977). Larson, however, points out that this distinctive autonomy is not absolute: rather it is dependent because it has been granted by society. Larson comments,

Professions ultimately depend upon the power of the state, and they originally emerge by the grace of powerful protectors. The privileged position of a profession 'is thus secured by the political and economic influence of the elite which sponsor it.' (p. xii)

Larson suggests that autonomy is not a static, fixed professional characteristic but changes and evolves through the course of the profession's relationship with society. Autonomy is gained and it can be lost. Moreover, Larson suggests that professional boundaries and control are negotiated through struggle and persuasion but once achieved they are protected by autonomous powers of self-evaluation and self-control that can immunize a profession from external regulation. Thus, the most visible method of establishing occupational control lies in the monopoly of the licensing process of a profession whereby a government grants exclusive official permission either by public statute or private charter to individuals who meet the profession's admission criteria. Thus, the standards for admission to practice which include the LL.B. granted by the law school are a key to the Law Society's autonomous power.

Scholars are divided as to whether professional autonomy is in decline. Some scholars suggest that a transformation of professions is underway with the erosion of autonomy, the encroachment of professional monopolies of expert services, and increasing external government intervention and regulation (Larson, 1972). Others argue that professional autonomy remains intact (e.g., Curry \& Wergin, 1993; Eraut, 1994; Freidson, 1986). Eliot Freidson (1986) approaches the issue by asserting 
that occupational licensing and credentialing continues to allow the professions to control admission to their ranks thereby regulating their membership. What is clear from the literature is that professional control over their own education is essential to their future survival.

\section{THE CASE OF LEGAL EDUCATION IN ONTARIO}

\section{Professional Autonomy and Self -Governance:}

\section{Setting Standards for Admission to Practise}

It is helpful to consider the organization and governance of the legal profession in Ontario in order to place this discussion into context. The legal profession in Ontario is a self-regulated professional body governed by public statute, The Law Society Act, R.S.O. 1998. The governing body of the profession is the Law Society of Upper Canada and the governing council are the Benchers of the Law Society known as Convocation. They include forty elected benchers who are members of the profession, four lay benchers who are representatives and appointees of the Lieutenant Governor in Council and other ex officio and honourary benchers (Cumming, 1989; Stager \& Arthurs, 1990). Although the law profession, like others, can be described as "self-governing," both federal and provincial legislation limit its autonomy. The profession is subject to civil and criminal laws and they are subject to laws that regulate collective or corporate behavior of groups. The legislation that confers self-governing powers on the Society also sets parameters on those powers. If the Society attempts to regulate its members in matters not covered by statute, its actions can be successfully challenged in court.

With the right to professional self-governance comes increased public accountability, the obligation to protect vulnerable interests, and fairness of regulations. The fundamental obligation of a self-regulated profession, such as the law profession, is the protection of the public interest through the setting of standards for entry to the profession and the certification of competency. In exercising this obligation the profession must reconcile the interests that it serves: it must balance the rights of the professional body with the rights of the public it is bound to protect (Stager \& Arthurs, 1990; Role Statement, The Law Society of Upper Canada, 1996). ${ }^{1}$ 
As a self-governing body, one of the primary functions of the Law Society is to determine who will be admitted to membership and the practise of law in the province. It does this through licensing, the most restrictive of the three potential credentialing models. ${ }^{2}$ The regulation governing entry to the licensing Bar Admission Course states that an applicant must have either an LL.B. degree from an "approved" Canadian law school or a Certificate of Qualification issued by the National Committee on Accreditation appointed by the Federation of Law Societies of Canada and the Committee of Canadian Law Deans. All sixteen common law schools at Canadian universities have been approved by the Law Society of Upper Canada. Therefore, their graduates are permitted to seek licensing in the profession in Ontario. ${ }^{3}$

\section{The Law Society and the LL.B.}

It should be clarified that while the Law Society of Upper Canada has formal power of approval of law schools, it does not have an accreditation department, staff or resources committed to the regular auditing of the law schools, their courses and faculty. Unlike parallel professions such as medicine and engineering, the law profession in Ontario does not conduct a formal, rigorous process by which the quality of a law school is evaluated and accredited (Stager \& Arthurs, 1990). The Law Society's power of approval is exercised in the requirement of the seven mandatory courses which comprise a core curriculum across the law schools. This allows the Law Society to formally stipulate minimum curricular requirements on the university-based LL.B. ${ }^{4}$ However, the structure, content, teaching methods and assessment, and faculty are not specifically regulated by the Law Society. How these courses are taught, and by whom is not monitored. The requirement is satisfied simply if the courses are taught. A wide range of courses are offered across the law schools and much controversy exists over what courses should be mandatory and how they should be taught and evaluated given the changing practise of law and changing pedagogy in adult and higher education. Although formal mechanisms for accountability and quality control are not employed by the Law Society when it comes to the university-based LL.B., it would appear that the Law Society exercises influence through discussion, 
diplomacy and informal mechanisms of influence rather than through explicit regulatory measures. ${ }^{5}$

\section{The Development of University-based Law Schools}

In 1889 Osgoode Hall Law School was established permanently at the Law Society. The law program included lectures, exams, articling and a stay in residence at Osgoode Hall at the Law Society. After the Second World War, transformations took hold of the universities with the flood of veterans entering higher education. Support was garnered at this time for the view that the practise of law required an academic and practical training. But the shift toward university-based legal training in common law schools in Canada is largely attributed in the legal literature to the dramatic changes occurring in American legal education after the war (Stager \& Arthurs, 1990). Canadian legal scholars in the 1950s went across the border to Harvard University and other American universities in order to attend post graduate legal studies unavailable in Canada. The American law schools emphasized formal legal training and profoundly influenced the direction Canadian legal education was to take in the post war period. The profession recognized that university education and credentials were necessary for the profession to maintain status and prestige, not to mention control over expertise, in a rapidly changing society. It is suggested that the gradual displacement of practical apprenticeship training by academic instruction reflected the expanding nature of legal knowledge and the belief that articling alone was an inadequate preparation for the practice of law (Stager \& Arthurs, 1990).

The late development of formal legal education in Canada (as compared to Britain and the United States) has been attributed to the debate over the appropriate preparation for law practise and whether the Law Society or the university should be responsible for the professional training of lawyers. This debate has existed since the inception of the Law Society in 1797 without consensus on the objectives, structure and content of legal education (Baker, 1983; Stager \& Arthurs, 1990). Finally, in 1957 , the Law Society agreed that admission to practice would require the university law degree. Admission to law school would require a minimum of two years in a university undergraduate program and the law 
degree would require full time attendance in a three year program. The existing law program at Osgoode Hall Law School continued at the Law Society along with the LL.B. programs that began at the university law schools. The Law Society also continued to administer the articling period and the Bar Admission Course. Shortly after this agreement other law faculties were established across southern Ontario. ${ }^{6}$ In 1968 the Law Society handed over its law program to York University. Today the academic portion of legal training for admission to the practise of law in Ontario is entrenched in the university-based law school in the form of the LL.B. The practical portion of legal training is found in the Bar Admission Course run by the Law Society.

\section{Institutional Autonomy of the University and the Law Schools: Setting Standards for the Law Degree}

It is helpful to explore the autonomous nature of the university institution in order to understand the significance of the movement of legal training from the Law Society to the law schools. Institutional autonomy of the university is defined in the literature in terms of four freedoms including the freedom to determine admissions, hire staff, set curriculum, and conduct research (Winchester, 1985). Historically, universities in Europe and North America were funded by students, royalty or the church (Jones, 1996; Winchester, 1985). This reliance on outside sources of revenue left universities vulnerable to encroachments on their autonomy as under each arrangement demands were made on the university with respect to the freedom to manage their own affairs. More recently, with the onset of industrialization, government and business have replaced these earlier forces as challenges to university autonomy (Winchester, 1985).

In Canada the present relationship between the university and government evolved with the governance structure of the university. Specifically, The Royal Commission on the University of Toronto in 1906 (known as the Flavelle Commission) had an important influence on the development of Canadian universities. Its recommendations included divorcing the governmental powers of the university from the direct superintendence of political powers. In a governance model called bicameralism provincial 
powers were vested in a corporate board made up of government appointed members to govern administrative affairs while an academic governing board retained control over academic issues (Jones, 1996). This development positively influenced university institutional autonomy removing it from partisan interference from the government.

Jones (1996) comments that, although universities in Ontario relied upon public support, they were subject to little government control. This was, in part, because of the general consensus between political leaders and university administrators about the role and objectives of public universities which left little reason for intervention in university affairs. Early relationships between universities and governments are described as "relatively harmonious and non-bureaucratic" (Jones, 1996, p. 348). However, this changed after the Second World War with the expansion and redefinition of the university sector. Consensus on the role and function of the university shifted dramatically with increasing interest in scientific research. The university took a larger role in national policy and began to be seen by the government as an instrument to achieve government objectives in various aspects of society.

By 1966 the Duff-Berdahl Commission recommended modifying the governance structure to allow for greater internal democratization within the framework of bicameralism through increased participation by faculty, and to a lesser extent, by students. Jones (1996) distinguishes between the developments of the 1906 and the 1966 commissions in this way:

While the governance model which emerged in the early years of the twentieth century had largely been an attempt to clarify university government relations while retaining some element of external accountability, the new pressures for change represented a demand for greater internal accountability to the university constituencies. (p. 355)

Although the changes made varied by university, generally three modifications were seen because of the 1966 commission including a stronger senate, greater faculty and student participation and a move to a more open, transparent decision-making process (Jones, 1996). While the developments arising from the Flavelle Commission in 1906 resulted in increased university autonomy from the government, the developments of 
the Duff-Berdahl Commission in 1966 had the opposite effect. The evolution in the democratic internal functioning of the university decreased the institutional autonomy of the university. Greater faculty participation in university affairs led to the movement toward unionization and collective bargaining as a way of increasing professoriate job security and protecting individual rights. This activity is governed by procedural and substantive labour relations laws and regulations. Consequently, the mobilization of university faculty and staff attracted the application of federal and provincial regulations governing labour relations, thereby inviting further government intervention into the internal administrative affairs of the university.

Cutt (1990) comments that the university, during this period of growth, increasingly came under government control because the expansion of the sector was funded by the government. Although the universities retained a high degree of autonomy on decision-making related to academic matters, they were called upon to account financially for the large sums of money going to the university to ensure they were being spent to meet the public's need. A number of accountability mechanisms were used by the government including financial audits, budgetary approval, and control exercised through the board of governors (Cutt, 1990). ${ }^{7}$ The literature suggests that presently there is a move on the part of governments to increase external accountability and governments are reconsidering their regulatory relationships with universities considering "a more directive approach to higher education policy so that universities will be more responsive to government objectives and priorities. Changes such as these will obviously have an impact on institutional autonomy and the nature of the provincial policy communities" (Jones, 1996, pp. 367-368). To summarize, external challenges to university autonomy came in the form of increased government regulation and independent mechanisms to meet calls for accountability to mainstream society. Internal challenges to university autonomy arose with changes in the decision-making process as a result of increased faculty participation and labour related mobilization which had the effect, if not the intention, of attracting government regulation to activities within university affairs. 
Notwithstanding the government's move to curtail university autonomy through the use of accountability mechanisms associated with funding, the literature in this area describes the high level of autonomy allowed to the university by the provincial government and suggests that Canadian universities, although public, have as much or more autonomy in managing their affairs than other public universities in the world (Cutt, 1990; Cutt \& Dobell, 1990; Horn, 1984; Jones, 1991; Jones, 1996; Skolnik \& Jones, 1992; Winchester, 1985). Moreover, the recent Report of the Task force on University Accountability (1993) observed that one of the greatest strengths of Ontario universities is the high degree of institutional autonomy they enjoy. The report notes that the government has given universities a large degree of freedom to develop their own academic programs and to manage their own affairs in order to encourage the growth of strong institutions of higher learning. Consequently, individual institutions have been free to determine how they will fulfill their broad mandates and have done so in diverse ways (Report of the Task Force on University Accountability, 1993).

Given the embeddedness of the university within the social fabric of societies and its dependence upon the government for funds, it is difficult to conceive of a completely autonomous university. Ontario universities lack economic independence from the society that surrounds them. Winchester (1985) argues the university is an integral part of society and activities within the university play "a central economic, social and cultural role in the modern state" (Winchester, 1985, p. 36). Since the government is responsible for the co-ordination of that state, under the circumstances, Winchester suggests that government regulation of the university's four freedoms is a "fact of our times" (Winchester, 1985, p. 34). He comments that complete autonomy for a university is both difficult to define and even harder to substantiate as it is subject to government pressure and even direct interference.

\section{The relationship between the Law Society and the law schools: Negotiating Autonomy in Legal Education}

Winchester (1985) distinguishes between the autonomy of self-governing bodies and institutional autonomy of the university suggesting 
that, in Canadian universities, the common institutional pattern with a legally autonomous governing board is not in the same class as selfgoverning institutions but is dependent on the government (or a religious body) for its appointments. Thus, the "self governing" status of the professional association has a different brand of, and perhaps greater, autonomy than the institutionally autonomous university. However, the governing body of the Law Society of Upper Canada also includes government appointments. Moreover, scholars in the literature (e.g., Curry \& Wergin, 1993; Eraut, 1994; Freidson 1986) argue that the greatest challenges to professional autonomy today come from government efforts to interfere and limit their power. In this respect, the most serious challenges to autonomy for both the university-based law schools the Law Society come in the form of government interference.

Institutional autonomy of the university cloaks the law schools and largely protects the law faculty from external or uninvited interference in their academic affairs. Although the autonomy is not complete and is subject to the constraints described above, it does give the law schools (within the structure of the university) the freedom to manage admissions, hire faculty, set curriculum, and direct the course of its research. This characteristic of the university-based law schools affects the Law Society's role in legal education and ultimately determines the relationship between the two bodies. Although the Law Society must officially "approve" law schools and their LL.B. degree in order for the graduates of such programs to be admitted into practise, the reality is that the Law Society does not function as an accreditation body. It has no direct input into the internal decision-making power of the law school, not does it have the means or the resources to monitor or audit the LL.B. Dennison's (1995) comments on institutional and professional accreditation shed light on the Law Society's position. Speaking first about institutional accreditation in Canada, Dennison states,

In the Canadian tradition of postsecondary education, the term 'accreditation' has very limited application, partly because no national governing system or regulatory body exists, and partly because institutional autonomy, in the university sector at least, has become a dominant characteristic of the system. (p. 236) 
However, Dennison acknowledges important exceptions to this, such as the role played by professional accrediting agencies which require institutional conditions to be met in order for graduates from an institution to obtain admission to particular professions. Nevertheless he states that professional accrediting bodies are primarily concerned with programs as opposed to institutions and he comments that 'formal accreditation of institutions is not practised in Canada' (Dennision, 1995, p. 236).

The Law Society does not function as an institutional accrediting agency in relation to the university, nor is it an official professional accrediting body of the law program within the university. The Law Society stands as an external agency in relation to the law schools which makes its ability to impose accountability measures on the law schools tenuous. The Law Society's position raises problems for self governance because of the disagreement on the role of legal education: the diverse (and often conflicting) priorities of the academic world do not always meet the training needs of professional practise. The Law Society's efforts to hold the law schools accountable to the profession for the training of lawyers runs up against the university's institutional autonomy. However, as Dennison's (1995) comments suggest approval of the law program does not have to interfere with the university's institutional autonomy if the focus of the professional association is the program and not the institution, its activities, its mission, or management. Accountability to the Law Society does not have to undermine the university's autonomy. The law schools can, within their own mandate, attempt to satisfy the needs of the public, and the profession. Given that the faculty are themselves members of the law profession they have an interest to do so.

It could be argued that the Law Society could simply withdraw its approval of law schools and refuse to accept graduates. However, the Law Society is not in a position in these times of economic constraint to resume its original role in educating new recruits to the profession. It needs the law schools to perform this function. Therefore it has devised other means beyond formal accreditation to influence the law schools. This can be seen through the efforts and agency of individual members of the society who teach at the law school. Moreover, increasing corporate 
sponsorship by law firms who represent a powerful employer of law graduates influence the type of courses that are offered at the law school. In this way legal education has been characterized "largely a result of the interplay of several kinds of pressures and constraints" through the claims made by multiple and diversely interested constituencies (Bok, 1986, p. 82). Professional faculties retain substantial control over the content and the methods of education, but are subject to significant pressure from several constituencies in exercising this power. University autonomy is besieged by government, the industry, and professional associations. The law faculty must fashion their response to all of these interests within the context of their own mandate.

An example of competing influences on the law schools can be seen in the law school budget within the university which serves to control and constrain the law school more than any restrictions made by the Law Society. Stager and Arthur (1990) explain that in Ontario the disciplinebased funding formula adopted by the government in 1967 was based on prevailing expenditures in each faculty:

Since expenditures in law school were much lower than in other professional faculties, such as medicine and engineering, the formula by which provincial grants were determined for each university accorded law school enrolments a weight equal to that for undergraduate honours programs. Although it was in effect a graduate program (since it led to a second degree for most students) enrolments in social science and humanities at the master's degree level received a grant per student twice that associated with LL.B. students. (p. 117)

The resulting budgetary pressures of the law schools who were expected to provide American style education, specialized libraries, computers, journals, and salaries for faculty that competed with private law firms forced the law schools to enter into innovative corporate arrangements which make the law schools answerable to the corporate interests invested in the schools. (Stager \& Arthurs, 1990). The Law Society's curricular interests fall to the back of the line unless the Society can align them with the multiple interests the law school serves. 
The impact of government funding levels can also be seen in enrolment issues. Some of the major constraints on the number of law students and, thus, the prospective lawyers entering the profession in Ontario are government policy on the number of law schools and levels of funding. Enrolment in law programs is controlled by the law schools based on the provincial government's funding formula. ${ }^{8}$ It is in the law school's interest to increase their numbers and their presence within the university. Increasing enrolment also fuels competition between law schools for potential applicants. However, for the Law Society who receives these graduates for licensing, swelling ranks in the membership increases competition within practice thereby having detrimental effects on professional competence and conduct. This presents governance difficulties for the Law Society in terms of regulation of standards of practice leading to calls from the profession to curb the numbers entering the law schools, calls which have been largely unheeded by the law schools. According to Stager and Arthurs, "constraint now is imposed entirely by government policy and financing" (Stager \& Arthur, 1990, p. 124). The law school's control over enrolment in its program, subject to government regulations, gives it major gate-keeping powers for the profession and undermines the Law Society's ability to control the size of its ranks.

\section{IMPLICATIONS FOR LEGAL EDUCATION}

The Law Society's self-governing obligations require the protection of the public through the setting of standards for admission and competence for the practice of law. This role requires involvement in the legal training at the law school because the LL.B. is a requirement for admission to practice. By handing over this requirement for admission to practice of law to the law schools, the Law Society has handed over primary control of the standards of entry into practice, initial training and acculturation of prospective lawyers, and the direction of the profession's future through research. The law school's control of legal education is almost complete, covering admissions, hiring faculty, research and subject to only minimum, and unmonitored, curriculum requirements for Law Society approval of the program. In assuming a major component 
of legal education for the profession, law schools now supply the knowledge that gives the profession its claim to specialized expertise and competence, underpinning society's grant of autonomy. Moreover, since education shapes professional behavior, institutions that train new recruits play a key role in the development of the profession and in the socialization of young professionals. The law school's control over initial training and fundamental research in the profession gives it the power to shape legal knowledge and influence the direction of the profession. Thus, the law schools inform the professions' "intellectual paradigm" through research, moulding successive generations of students, influencing law reform and legislative innovation (Stager \& Arthurs, 1990 , p. 85). The activities of the law school in advancing legal knowledge in breadth and depth represent a challenge to established understanding of the legal rules, creating tension between the professional association and the law schools.

While all the stakeholders in professional legal education share the belief that society must have competent practitioners trained to serve the needs of the clients, they also recognize the need to produce new knowledge to enlighten professional practice. Bok (1986) observes that beneath the general agreement of principle there are fundamental differences in emphasis and perspective in professional education between practitioners and academics. This different perspective can influence the way in which the academic and the practising professsional worlds define competence and professional responsibility. It also complicates developing mechanisms for accountability as professional schools and professional societies often serve conflicting interests. Discussions of accountability must address: accountability to whom? for what? and in what form? The answers to these questions may vary in professional education depending on one's location in either the academic or practising world. The law schools see their mandate as broader than just skills training in preparation for practice. Although law schools provide some opportunity for practice-oriented skills development they do not see themselves as uniquely preparing law students for the licensing process. By contrast a central responsibility of the Law Society is ensuring the provision of competent legal services to the public through the development and 
assessment of the knowledge, skills, attitudes and values upon which competent practice depends. Consequently, the Law Society as governing body of the profession and bar examiner must address any competency gap between law school and practice in their bar admission program. ${ }^{9}$

\section{CONCLUSIONS}

The legal profession in North America has wrestled with these recurring issues about legal education for decades, as evidenced by the observations of Dean Langdell of Harvard Law School over a century ago,

...legal education must be concerned with more than vocationalism to justify its inclusion among the functions of a university. There must be discovery of new knowledge, organization of old knowledge, and appropriate concerns for the problems that beset us as a nation and a society. (as cited in Allen, 1979, p. 52)

At the core of the debate within legal education are the aims of legal education, the definition of legal knowledge and the nature of legal practice. Is the university the proper place to educate lawyers? Is the role of the law school to prepare students for the problems of professional law practice or, to prepare them for the problems of the larger society? Is the primary function of legal education intellectual development or vocational preparation? Or both? And who should decide? the profession, the academy, the students, or the public which both the profession and the university serve?

Discussions of autonomy in higher education are not one dimensional given the multifunctional tasks of institutions and competing interests and values that are enmeshed in a web of multiple relationships. Institutions are accountable to multiple bodies for multiple reasons (Klause \& Hufner, 1991). Inevitably there are limitations to analyses that attempt to understand the nexus between different organizational cultures. The applicability of a single framework to capture and conceptualize the complexity of the relationship between the Law Society and the law schools is, consequently, limited. A purely sociological approach to these issues assumes, incorrectly, that the law profession is homogenous and acts as 
one body. In fact the law profession is made up of diverse groups that increasingly have little in common in terms of economic, intellectual and professional interests and values. The law profession is not unified or cohesive. Its common professional culture is gradually dissolving (Stager \& Arthur, 1990). This affects the institutional organization of the profession, strains the self-governing obligations of the Law Society and complicates any discussion of professional autonomy. Moreover, this framework does not adequately illuminate the position of legal academics who belong to two professional worlds. It fails to capture the dynamics of transformation when professions, such as law, undergo change or come into contact with other institutional cultures. The limitations of this approach in defining the issues in higher education where multiple disciplines converge invites further inquiry within and across different theoretical frameworks. Finally, suggested by the analysis, but beyond the scope of this paper, is a consideration of the role of the law firms in legal education and their influence on the governing body of the profession and the law schools as a large and powerful constituency and employer in the professional membership.

Legal education in Ontario has moved from the hands of a private incorporated self governing professional body into the hands of a publicly funded institution regulated by government and courted by business. The move of professional legal training to the university has had a positive effect on the professional status and power of the law schools within the profession and within the university, to the detriment of the Law Society. It has redefined the roles and relationships between the bodies, reversing the traditional position of dominance occupied by the Law Society in legal education. Although, as Winchester (1985) points out, the autonomous nature of the university is not absolute and does not match the autonomous powers of self-governing associations, the law schools have proven resilient. The increasing power and independence of the university-based law schools have, correspondingly, contributed to the decline of the professional power of the Law Society. Legal education is central to professional power in a number of ways. Professional expertise which grounds society's grant of autonomy and self-governance lies in the systematic body of knowledge and intellectual base that 
is first developed in the law school. Moreover, legal education provides the formal training that socializes young lawyers into the legal community and their professional roles and values. Law school is the gateway to the legal profession. It controls first entry to the profession in that the LL.B. (or its deemed equivalent) is the initial educational requirement for admission to practice. In all of these activities the law schools have taken over some of the fundamental self-governing professional powers held by the Law Society. The negotiation of autonomy within the relationship between the Law Society and the law schools has powerfully affected and defined the future of legal education and, ultimately, the profession. In order to meet the public's expectations for professional accountability an approach to legal education must be developed that respects the obligations of professional schools and professional societies and incorporates their common missions, values and interests. The autonomous nature of these bodies responsible for legal education pose challenges and opportunities for an integrated vision in the educational continuum from law school to law practice.

\section{Notes}

1 The Law Society of Upper Canada (LSUC) Role Statement, which acts as a standard against which policy and programs can be measured, emphasizes the Law Society's dual commitment to serve the interests of both the public and the individual members of the profession (Benchers Bulletin, 1996). The LSUC Role Statement states:

The Law Society of Upper Canada exists to govern the legal profession in the public interest by:

- ensuring that the people of Ontario are served by lawyers who meet high standards of learning, competence and professional conduct; and

- upholding the independence, integrity and honour of the legal profession, for the purpose of advancing the cause of justice and the rule of law. (Benchers Bulletin, 1996, p. 3) 
2 The three models of credentialing include: registration, certification, and licensing. Registration requires that individuals who offer a service be registered with a designated authority. Requirements for registration provide some opportunity for control of services. Certification informs the public that practitioners have satisfied an examining body of ability to practice at a minimum acceptable standard of competence. Those who are not certified are prevented from using the title or designation, but not from practising without. The LSUC requires a law degree and further professional training to be registered as a member in the Society. Since only members can practice law in Ontario, this forms a type of registration and certification. The most restrictive of the models is licensing which creates a monopoly on the provision of services; that is, it conveys an exclusive right to engage in a business or occupation and those licensed have been given an exclusive name or title (Stager \& Arthurs, 1990, p. 44).

3 The relationship between the provincial law societies across Canada and the Federation of Law Societies of Canada is outside the scope of this paper but needs to be considered. Briefly, the Federation of Law Societies of Canada and the Council of Canadian Law Deans established the National Committee on Accreditation (NCA) which, in addition to accrediting the credentials of foreign trained lawyers, has the responsibility to assess and recommend to the Law Societies the recognition of new full-time and part-time or joint degree programs from all Canadian law schools. However, the provincial Law Societies have the final decision of approval in the case of new programs. Moreover, the NCA does not approve existing law degree programs at Canadian common law schools. The Federation and the Council of Law Deans agree to a common core of requirements in the L.L.B programs across Canadian common law schools, but each Law Society retains the ultimate decision of approval of law schools' LL.B. degrees.

4 The LSUC requires three years of full-time study for the LL.B. This requirement is under review at some law schools. Six fields of law are compulsory at all common law schools in Canada, including Canadian Constitutional Law, Contracts, Criminal Practice, Criminal Procedure, Property and Torts Law. Three other areas are compulsory at half of the other common law faculties, including Administrative Law, Evidence, and Legal Research (Stager \& Arthurs, 1990). The LSUC requires seven courses: Contracts, Torts, Canadian Constitutional Law, Civil Procedure, Criminal Procedure and Criminal Law, Real and Personal Property. There are other courses that must be taught, but which are not mandatory. 
5 Informal mechanisms of influence might include, but not be limited to, university representation among the Benchers of the Law Society and, conversely, law society members within law school curriculum and governance committees.

6 Faculties of law were established at the University of Ottawa and Queen's university in 1957, at The University of Western Ontario in 1959, at the University of Windsor in 1967 and at Osgoode Hall at York University in 1968. It is interesting to note that this was not the first time universities had established law programs. As early as 1889 , the University of Toronto had started a four year bachelor of laws program in a new law faculty which included a three year arts program and a fourth year of practical law. But the Law Society did not recognize the degree and continued to require attendance at its own program for admission into the practice of law. Consequently, the University of Toronto withdrew its program in 1894 (Stager \& Arthurs, 1990, p. 87).

7 Cutt (1990) describes two sets of instruments employed by the government for controlling universities. He distinguishes them as "prospective" and "retrospective." The former is directed at limiting decision-making autonomy of university through controls on board memberships, planning and budgeting requirements, and constraints on the use of resources through specific conditions on funding by governments. After providing funding, "retrospective" measures are then used to increase university accountability for the funds through the use of report and audits.

8 Recent changes in university tuition regulations in Ontario may affect enrolment in professional schools

9 Presently in Ontario the Bar Admission Course is undergoing reform with a call for more practical skills-oriented training in the pre-call to the bar licensing education program. The increased emphasis on skills in both the type of knowledge and the type of testing for competence reflects a trend in legal education across Canada and in Australia, the United Kingdom and the United States where there is growing discussion among legal educators and practitioners about the need to improve the level of lawyer's skills, values, and competence in legal education (Task Force on Bar Admission Reform, 1998). 


\section{References}

Abbott, A. (1988). The system of professions: An essay on the division of expert labour. Chicago, IL: University of Chicago Press.

Abbott, P., Wallace, C. (Eds.). (1990). The sociology of the caring professions. London: Falmer.

Abel, R. (Ed.) (1997). Lawyers: A critical reader. New York, NY: The New Press.

Allen, F. (1979). Law, intellect, and education. Ann Arbor, MI: The University of Michigan Press.

Arthurs, H. (1975). Materials on the Canadian legal profession. Toronto, ON: Osgoode Hall Law School.

Baker, G.B. (1983). Legal education in Upper Canada 1785-1889: The Law Society as educator. In D. Flaherty (Ed.), Essays in the history of Canadian law. (Vol. 2), (pp. 49-142). Toronto, ON: Osgoode Society.

Bella, L. (1996). Professions as ideology. In Bill Kirwin (Ed.). Ideology, development and social welfare (3rd ed., pp. 145-164). Toronto, ON: Canadian Scholars' Press.

Bloom, S.W. (1988). Structure and ideology in medical education: An analysis of resistance to change. Journal of Health and Social Behavior, 29 (Dec.), 294-306.

Bok, D. (1986). Higher learning. Cambridge, MA: Harvard University Press.

Carr-Saunders, A.M., \& Wilson, P.A. (1933). The professions. London: Oxford University Press.

Cavanaugh, S.H. (1993). Connecting education and practice. In L. Curry, \& J. Wergin (Eds.), Educating professionals: Responding to new expectations for competency and accountability. San Francisco, CA: Jossey-Bass.

Coburn, D. (1992). Freidson then and now: An internalist critique of Freidson's past and present views of the medical profession. International Journal of Health Services, 22(3), 497-512.

Cumming, P. (1989). Access! Task Force on access to professions and trades in Ontario. Toronto, ON: Ontario Ministry of Citizenship.

Cutt, J. (1990). Universities and government: A framework for accountability. Halifax, NS: Institute for Research and Public Policy.

Cutt, J., \& Dobell, R. (1990). Accountability and autonomy in Canada's university sector: Business as usual or the lull before the storm? In R. Watts \& J. Greenberg (Eds.) Post-secondary education: Preparation for the world of work. U.K.: Aldershot. 
Dennison, J. (1995). Accountability : Mission impossible? In J. Dennison (ed.). Challenges and opportunity: Canada's community colleges at the crossroads, (pp. 220-242). Vancouver, BC: UBC Press.

Dingwall, R., \& Lewis, P. (Eds.). (1983). The sociology of the professions: Lawyers, doctors and others. London: MacMillan.

Dvorkin, E., Himmelstein, J., \& Lesnick, H. (1981). Becoming a lawyer: A humanistic perspective on legal education and professionalism. St. Paul, MN: West Publishing Co.

Elliot, F. (1972). The sociology of the professions. New York, NY: Herder and Herder.

Eraut, M. (1994). Developing professional knowledge and competence. London: The Falmer Press.

Freidson, E. (1986). Professional powers. Chicago, IL: The University of Chicago Press.

Freidson, E. (1994). Professionalism reborn: Theory, prophecy, and policy. Chicago, IL: The University of Chicago Press.

Gibson-Graham, J.K. (1996). The end of capitalism. Cambridge: Blackwell Publishers.

Gidney, R.D., \& Millar, W.P.J. (1994). Professional gentlemen: The professions in nineteenth century ontario. Toronto, ON: University of Toronto Press.

Gold, N. (Ed.). (1982). Essays in legal education: Centre for Studies in Canadian Legal Education. Toronto, ON: Butterworths.

Goldsmith, A. (1996). Heroes or technicians? The moral capacities of tomorrow's lawyers. The Journal of Professional Legal Education, 14(1), 1-23.

Habermas, J. (1971). Toward a rational society. Boston, MA: Beacon Press.

Horn, M. (1984). Government funding and the independence of teaching and scholarship. In I. Winchester (ed.), The independence of the university and the funding of the state: Essays on academic freedom in Canada. Toronto, ON: OISE Press.

Hufner, K. (1991). Accountability. In P. Altbach (ed.), International higher education: An encyclopedia, (vol. 1), (pp. 47-58). New York, NY: Garland Publishing, Inc.

Jarvis, K. (1984). Letter to the Law Society of Upper Canada re: Approved Canadian LL.B. Degrees. In Mr. Justice Roy J. Matas, \& D. McCawley, (Eds.) (1987), Legal education in Canada, (pp. 821-826). Montreal, QC: Federation of Law Societies of Canada.

Johnson, Terrance. (1992). Professions and power. London: Macmillan Press. 
Jones, G. (1991). Modest modifications and structural stability: Higher education in Ontario. Higher Education, 21(1) 90-104.

Jones, G. (1996). Government, governance and Canadian universities. In J.C. Smart, (ed.), Higher education: Handbook of theory and research (vol. xi), (pp. 337-371). New York, NY: Agathon Press.

Krause, E.A. (1971). The sociology of occupations. Boston, MA: Little, Brown.

Larson, M. (1977). The rise of professionalism: A sociological analysis. Berkeley, CA: University of California Press.

Law Society of Upper Canada. (Dec. 1997). Governing in the public interest. Toronto, ON: LSUC.

LSUC Role Statement. (1996). Bencher's Bulletin, Nov. 1996, 3. Toronto, ON: The Law Society of Upper Canada.

Maru, O. (1986). Research on the legal profession. Chicago, IL: American Bar Foundation.

Matas, Mr. Justice R.J., \& McCawley, D. (Eds.). (1987). Legal education in Canada. Montreal, QC: Federation of Law Societies of Canada.

McCrate. (1992). Legal education and professional development - An educational continuum: Report of the Task Force on Law Schools and the Profession: Narrowing the gap. Chicago, IL: American Bar Association.

McGuire, C.H. (1993). Sociocultural changes affecting the professions. In L. Curry \& J. Wergin (Eds.), Educating professionals: Responding to new expectations for competence and accountability, (pp. 3-16). San Francisco, CA: Jossey-Bass Publishers.

Menkel-Meadow, C. (1994). Narrowing the gap by narrowing the field: What's missing from the McCrate Report of skills, legal science and being a human being. Washington Law Review, 69, 593-624.

Mentkowski, M., Loacker, G., \& O’Brien, K. (1998). Ability-based learning and judicial education: An approach to ongoing professional development. Michigan: JERITT.

Millerson, G. (1964). The qualifying associations: A study of professionalization. London: Routeledge.

Moore, W.E. (1970). The professions: roles and rules. New York, NY: Russell Sage Foundation.

Pavalko, R.M. (1971). Sociology of occupations and professions. Itasca, IL: Peacock.

Podmore, D. (1977). Lawyers and politics. British Journal of Law and Society, 4, 155-185. 
Professional education: A policy option. (1972). A study prepared for the Commission on Post-Secondary Education in Ontario.

Robinson, L. (1987). Accreditation of law degrees programs. In Mr. Justice R.J. Matas \& D. McCawley, (Eds.), Legal education in Canada, (pp. 791-820). Montreal, QC: Federation of Law Societies of Canada.

Roman, A. \& associates. (1970). A study of legal education in Ontario. The Commission on Post-Secondary Education in Ontario.

Rueschemeyer, D. (1983). Professional autonomy and the social control of expertise. In R. Dingwall \& P. Lewis (Eds.), The sociology of the professions: Lawyers, doctors and others, (pp. 38-58). London: MacMillan

Schein, E., \& Kommers, D. (1972). Professional education. New York, NY: McGraw-Hill.

Severide, N. (1985). The role of the various organizations on the continuum of legal education in Canada. In Mr. Justice R.J. Matas \& D. McCawley, (Eds.) (1987), Legal education in Canada, (pp. 832-844). Montreal, QC: Federation of Law Societies of Canada.

Shils, E. (1968). The concept and function of ideology. In D. Shils \& R. Merton, (Eds.), Dictionary of the social sciences, (pp. 66-76). New York, NY: Macmillan.

Skolnik, M., \& Jones, G. (1992). A comparative analysis of arrangements for state co-ordination of higher education in Canada and the United States. The Journal of Higher Education, 63(2), 121-142.

Stager, D., \& Arthurs, H. (1990). Lawyers in Canada. Toronto, ON: University of Toronto Press.

Task Force on Bar Admission Course Reform. (1998). Bar Admission Course Reform Consultation Report. Law Society of Upper Canada.

The Law Society Act, R.S.O. 1998.

University Accountability: A Strengthened Framework: Report of the Task Force on University Accountability, May 1993.

Weber, M. (1954). Class, status, party. In H. Gerth \& C.W. Mills (Eds.), From Max Weber, (pp. 180-195). New York, NY: Oxford University Press.

Wilensky, H. (1964) The professionalization of everyone? American Journal of Sociology, LXIX (Sept.).

Winchester, I. (1985). The concept of university autonomy - an anachronism? In C.Watson (Ed.), The professoriate - Occupation in crisis, (pp. 29-42). Toronto, ON: Higher Education Group.

Witz, A. (1992). Profession and patriarchy. London: Routeledge. 